\title{
Pengaruh Pemberian Arang Sekam Padi dan Frekuensi Penyiraman Terhadap Pertumbuhan dan Hasil Tanaman Tomat (Lycopercicom esculentum, Mill)
}

\author{
Agustinus Kolo ${ }^{\text {a }}$ dan Krisantus Tri ${ }^{\mathrm{b}}$ \\ a Fakultas Pertanian, Universitas Timor, Kefamenanu, TTU - NTT, Indonesia. \\ ${ }^{b}$ Fakultas Pertanian, Universitas Timor, Kefamenanu, TTU - NTT, Indonesia.
}

\section{Article Info}

\section{Article history:}

Received 20 Februari 2016

Received in revised form 17 Maret 2016

Accepted 18 April 2016

\section{Keywords:}

Arang Sekam

Frekuensi Penyiraman

Lycopercicom esculentum, Mill

\begin{abstract}
Abstrak
Penelitian ini bertujuan untuk mengetahui pengaruh pemberian arang sekam padi terhadap pertumbuhan dan hasil tanaman tomat yang optimal serta memperoleh frekuensi penyiraman dalam memberikan pertumbuhan dan hasil tanaman tomat. Percobaan lapangan dilakukan di lahan Percobaan Fakultas Pertanian Universitas Timor pada bulan Agustus sampai Oktober 2015, mengunakan rancangan petak berjalur (strip plot design). Faktor pertama adalah takaran arang sekam, terdiri dari 3 level yaitu tanpa arang sekam padi, $0,5 \mathrm{~kg} / \mathrm{lubang}$ dan 1 $\mathrm{kg} /$ lubang. Faktor kedua adalah frekuensi penyiraman yang terdiri dari 3 level, yakni 1 hari sekali (pada sore hari), 3 hari sekali (pada sore hari) dan 5 hari sekali (pada sore hari). Parameter yang diamati meliputi: suhu tanah, kadar lengas tanah, tinggi tanaman, diameter batang,diameter buah, jumlah buah per tanaman, berat buah per tanaman, berat segar berangkasan, berat kering berangkasan dan indeks panen. Data dianalisis menggunakan uji DMRT 5\%. Hasil penelitian menunjukkan bahwa takaran arang sekam padi 0,5 kg memberikan hasil total panen per tanaman tertinggi yakni 646g (1,9 t/ha). Frekuensi penyiraman tiga hari sekali dengan taraf air selama 90 hari adalah 120 liter/tanaman memberikan hasil total panen per tanaman tertinggi yakni 705,7g (2,075 t/ha). (O2016 dipublikasikan oleh Savana Cendana.
\end{abstract}

\section{Pendahuluan}

Tomat merupakan tanaman sayuran yang penting karena buah toma mengandung vitamin $\mathrm{C}$ dan vitamin A yang memiliki banyak manfaat untuk kesehatan. Zat asam askorbat dan karoten, yang terkandung dalam tomat, merupakan sumber zat yang sangat penting dan dapat meningkatkan aktifitas tubuh. Kandungan vitaminnya dapat mencengah berbagai penyakit atau berfungsi sebagai obat sariawan, gusi dan rabun ayam, sehingga tomat tergolong sayuran yang memiliki nilai ekonomis tinggi (Susanto dan Saneto, 1994). Kandungan lycopene dalam tomat yang cukup tinggi dapat diekstrak untuk produk-produk kesehatan atau kosmetik mengingat kekuatan lycopene setara dengan kekuatan vitamin E dalam menanggulangi radikal bebas (Di Mascio, et al., 1989). Tepung sisa ekstraksi pun dapat dimanfaatkan menjadi bahan serea karena kandungan protein, serat, dan karbohidratnya yang cukup tinggi.

Dalam budidaya tanaman termasuk tomat, faktor lingkungan memegang peranan penting untuk mencapai pertumbuhan dan hasil yang maksimal. Hayat et al., (2012) menyatakan bahwa faktor lingkungan sangat berperan dalam proses pertumbuhan tanaman, media tumbuh adalah salah satu faktor lingkungan yang perlu dipertimbangkan. Selanjutnya juga dinyatakan bahwa media tanam yang baik biasanya digunakan campuran pasir, tanah, pupuk kandang. Penggunaan pasir sangat baik untuk perbaikan sifat fisik tanah terutama tanah liat. Osman (1996) menyatakan bahwa tanah dengan keadaan tekstur dan struktur yang baik sangat menunjang keberhasilan usaha pertanian, struktur tanah yang dikehendak tanaman adalah struktur tanah yang gembur mempunyai ruang pori yang beris air dan udara sehingga penyerapan unsur hara dapat berjalan optimal. Sekam padi juga dapat digunakan sebagai bahan media tanam, menurut Rifai dan Subroto (1982) sekam padi merupakan hasil sampingan dari sisa-sisa pembakaran. Unsur hara yang terkandung dalan sekan padi relatif cepat tersedia bagi tanaman dan dapat meningkatkan $\mathrm{pH}$ tanah.

Menurut data statistik di kabupaten Timor Tengah Utara (TTU) bahwa hasi tanaman tomat di tahun 2009 sampai 2012 masih rendah dan disebabkan karena teknologi dan sistim budidaya yang masih sederhana atau masih tradisional. $\mathrm{Ha}$ ini dapat ditinjau dari beberapa kecamatan antara lain dapat di lihat dalam Tabe

Tabel 1. Data produksi tomat di Kabupaten TTU Tahun 2009-2010

\begin{tabular}{lc}
\multicolumn{1}{c}{ Kecamatan } & Produksi (t/ha) \\
\hline Miomafo Barat & 20 \\
Mutis & 19 \\
Miomafo Timur & 20 \\
Insana Utara & 5 \\
Biboki Selatan & 15 \\
Biboki Utara & 15 \\
Biboki Anleu & 5 \\
\hline
\end{tabular}

Sumber BPS TTU 2009-2010

Sebagian kecil, petani menanam tomat pada musim hujan, namun umumnya membudidayakan pada musim kemarau. Kebiasaan petani umumnya menyiram dua kali yakni pagi dan sore hari. Untuk meningkatkan produksinya, pemeliharaan di musim kemarau membutuhkan banyak air (BPS, 2010).

Permasalahan usaha tani tomat adalah produksi masih rendah dibandingkan potensi produksinya. Untuk meningkatkan produksinya, berbagai cara dapat di lakukan melalui perbaikan teknologi budidaya seperti perbaikan varietas, pemupukan, pengendalian hama, dan penyakit, serta perbaikan pasca panen Kemampuan tomat untuk dapat menghasilkan buah sangat tergantung pada interaksi antara pertumbuhan tanaman dan kondisi lingkungan. Faktor lain yang menyebabkan produksi tomat rendah adalah penggunaan pupuk yang kurang optimal serta wadah media tanam yang belum tepat. Upaya menanggulangi kendala tersebut adalah memperbaiki teknik budidaya.
Penambahan arang sekam pada media tumbuh akan menguntungkan, di antaranya mengefektifkan pemupukan karena selain memperbaiki sifat tanah (porositas, aerase), arang sekam juga berfungsi sebagai pengikat hara (ketika kelebihan hara) yang akan digunakan tanaman ketika kekurangan hara, kemudian hara tersebut dilepas secara perlahan sesuai kebutuhan tanaman atau slow release (Komarayati et al. 2003). Namun penggunaan arang sekam selama ini lebih banyak pada budidaya tanaman hias dan belum diketahui takarannya yang tepat. Oleh karena itu perlu diadakan penelitian tentang bagaimana penggunaan takaran arang sekam padi dan frekuensi penyiraman yang tepat sehingga dapat memberikan pertumbuhan dan hasil tomat yang paling optimal

\section{Metode}

Penelitian dilaksanakan bulan Agustus sampai Oktober 2015 di kebun percobaan Fakultas Pertanian, Universitas Timor Kelurahan Sasi, Kecamatan Kota Kefamenanu, Kabupaten TTU. Rancangan penelitian yang digunakan adalah rancangan petak berjalur (strip plot design) faktorial $3 \times 3$ yang diulang dalam 3 blok. Faktor pertama adalah takaran arang sekam (S), terdiri dari 3 leve yaitu tanpa arang sekam padi. $\left(\mathrm{S}_{0}\right)$, takaran arang sekam padi $0,5 \mathrm{~kg} / \mathrm{lubang}\left(\mathrm{S}_{1}\right)$ dan takaran arang sekam padi $1 \mathrm{~kg} /$ lubang $\left(\mathrm{S}_{3}\right)$.Faktor kedua adalah frekwensi penyiraman $(\mathrm{F})$ yang terdiri dari 3 level, yakni frekuensi penyiraman 1 hari sekali (pada sore hari) $\left(\mathrm{F}_{0}\right)$, frekuensi penyiraman 3 hari sekali (pada sore hari) $\left(\mathrm{F}_{1}\right)$, frekuensi penyiraman 5 hari sekali (pada sore hari) $\left(\mathrm{F}_{2}\right)$

Data hasil pengamatan kemudian dianalisis dengan menggunakan sidik ragam (Anova) rancangan petak berjalur. Rata-rata perlakuan selanjutnya diuji lanjut dengan menggunakan Duncan Multiple Range Test (DMRT) dengan tingkat signifikasi 5\% sesuai petunjuk Gomez dan Gomez, (1995). Analisis data menggunakan program SAS 9.1.

\section{Hasil dan Pembahasan}

3.1 Suhu Tanah

Hasil sidik ragam (Anova) menunjukkan bahwa terjadi interaksi antara takaran arang sekam padi dan frekuensi penyiraman terhadap suhu tanah 25 HST dan 75 HST dimana suhu tanah pada petak yang diberikan arang sekam padi dengan takaran 0,5 g per lubang tanam kemudian disiram setiap lima hari sekali selalu paling tinggi.

Tabel 2. Suhu Tanah $\left({ }^{\circ} \mathrm{C}\right)$

\begin{tabular}{|c|c|c|c|c|c|}
\hline \multirow{2}{*}{$\begin{array}{c}\text { Waktu } \\
\text { Pengamatan }\end{array}$} & \multirow{2}{*}{$\begin{array}{l}\text { Arang } \\
\text { Sekam }\end{array}$} & \multicolumn{3}{|c|}{ Frekuensi Penyiraman } & \multirow{2}{*}{ Rerata } \\
\hline & & 1 Hari & 3 Hari & 5 Hari & \\
\hline \multirow{4}{*}{25 HST } & Kontrol & $32,9 \mathrm{c}$ & $30,5 \mathrm{~d}$ & $37,8 \mathrm{a}$ & $33,7 \mathrm{~b}$ \\
\hline & $0,5 \mathrm{~kg}$ & $32,8 \mathrm{c}$ & $35,4 \mathrm{~b}$ & 38,1 a & $35,5 \mathrm{a}$ \\
\hline & $1 \mathrm{~kg}$ & $31,0 \mathrm{~cd}$ & $31,3 \mathrm{~cd}$ & $36,8 \mathrm{ab}$ & $33,0 \mathrm{~b}$ \\
\hline & Rerata & $32,2 \mathrm{~b}$ & $32,4 \mathrm{~b}$ & $37,6 \mathrm{a}$ & $(+)$ \\
\hline \multirow{4}{*}{$50 \mathrm{HST}$} & Kontrol & 32,3 & 30,1 & 36,9 & $33,1 \mathrm{a}$ \\
\hline & $0,5 \mathrm{~kg}$ & 30,8 & 34,0 & 38,8 & $34,6 \mathrm{a}$ \\
\hline & $1 \mathrm{~kg}$ & 31,2 & 30,6 & 37,4 & $33,1 \mathrm{a}$ \\
\hline & Rerata & $31,4 \mathrm{~b}$ & $31,6 \mathrm{~b}$ & $37,7 \mathrm{a}$ & $(-)$ \\
\hline \multirow{4}{*}{75 HST } & Kontrol & $29,3 \mathrm{e}$ & $30,1 \mathrm{de}$ & $38,0 \mathrm{~b}$ & $32,5 \mathrm{~b}$ \\
\hline & $0,5 \mathrm{~kg}$ & $29,0 \mathrm{e}$ & $33,8 \mathrm{c}$ & $39,5 \mathrm{a}$ & $34,1 \mathrm{a}$ \\
\hline & $1 \mathrm{~kg}$ & $30,1 \mathrm{de}$ & $30,7 \mathrm{~d}$ & $36,8 \mathrm{~b}$ & $32,5 \mathrm{~b}$ \\
\hline & Rerata & $29,4 \mathrm{c}$ & $31,5 \mathrm{~b}$ & $38,1 \mathrm{a}$ & $(+)$ \\
\hline & lak t & miteraks & $\begin{array}{l}\text { ti deng } \\
\text { IRT. } \\
\text { ktor }\end{array}$ & sama & eda $p$ \\
\hline
\end{tabular}

Takaran arang sekam padi berpengaruh nyata terhadap suhu tanah 25 HST dan 75 HST dimana suhu tanah pada petak yang diberikan arang sekam padi dengan takaran $0,5 \mathrm{~g}$ per lubang tanam selalu paling tinggi dan berbeda nyata dengan suhu tanah pada petak yang tidak diberikan arang sekam padi dan suhu 
tanah pada petak yang diberikan arang sekam padi dengan takaran $1 \mathrm{~g}$ per lubang tanam. Saat 50 HST takaran arang sekam padi tidak berpengaruh nyata pada suhu tanah tetapi data Tabel 2., menunjukkan bahwa suhu tanah pada petak yang diberikan arang sekam padi dengan takaran $0,5 \mathrm{~g}$ per lubang tanam tetap lebih tinggi.

Frekuensi penyiraman berpengaruh nyata terhadap suhu tanah setiap waktu pengamatan dimana suhu tanah pada petak yang disiram setiap lima hari sekal selalu paling tinggi dan berbeda nyata dengan suhu tanah pada petak yang disiram setiap hari maupun setiap tiga hari sekali.

\subsection{Kadar Lengas Tanah}

Hasil sidik ragam (Anova) menunjukkan bahwa terjadi interaksi antara takaran arang sekam padi dan frekuensi penyiraman terhadap kadar lengas tanah 75 HST dimana kadar lengas tanah pada petak yang diberikan arang sekam padi dengan takaran $1 \mathrm{~kg}$ per lubang tanam kemudian disiram setiap lima hari sekali paling tinggi.

Takaran arang sekam padi tidak berpengaruh nyata terhadap kadar lengas tanah 25 HST tetapi data Tabel 3. menunjukkan bahwa kadar lengas tanah pada petak yang tidak diberikan arang sekam padi cenderung lebih tinggi. Saat pengamatan selanjutnya, arang sekam padi secara nyata berpengaruh terhadap kadar lengas tanah dimana kadar lengas tanah pada petak yang diberikan arang sekam padi dengan takaran $1 \mathrm{~kg}$ per lubang tanam selalu paling tinggi dan nyata berbeda dengan kadar lengas tanah pada petak yang diberikan arang sekam padi dengan takaran $0,5 \mathrm{~kg}$ per lubang tanam.

\begin{tabular}{cccccc} 
Tabel 3. Kadar Lengas Tanah $(\%)$ & \multirow{2}{*}{ Rerata } \\
\hline Waktu & Arang & \multicolumn{3}{c}{ Frekuensi Penyiraman } \\
\cline { 2 - 5 } Pengamatan & Sekam & 1 Hari & 3 Hari & 5 Hari & \\
\hline \multirow{3}{*}{25 HST } & Kontrol & 25,1 & 27,7 & 29,8 & $27,5 \mathrm{a}$ \\
& $0,5 \mathrm{~kg}$ & 22,8 & 22,0 & 18,9 & $21,2 \mathrm{a}$ \\
& $1 \mathrm{~kg}$ & 26,9 & 28,8 & 19,9 & $25,2 \mathrm{a}$ \\
\cline { 2 - 5 } & Rerata & $24,9 \mathrm{a}$ & $26,2 \mathrm{a}$ & $22,9 \mathrm{a}$ & $(-)$ \\
\hline \multirow{3}{*}{$50 \mathrm{HST}$} & Kontrol & 26,2 & 30,8 & 27,2 & $28,1 \mathrm{a}$ \\
& $0,5 \mathrm{~kg}$ & 18,7 & 17,0 & 16,5 & $17,4 \mathrm{~b}$ \\
& $1 \mathrm{~kg}$ & 30,5 & 27,9 & 27,7 & $28,7 \mathrm{a}$ \\
\cline { 2 - 5 } & Rerata & $25,1 \mathrm{a}$ & $25,3 \mathrm{a}$ & $23,8 \mathrm{a}$ & $(-)$ \\
\hline \multirow{3}{*}{$75 \mathrm{HST}$} & Kontrol & $30,2 \mathrm{a}$ & $28,5 \mathrm{ab}$ & $25,0 \mathrm{bc}$ & $27,9 \mathrm{a}$ \\
& $0,5 \mathrm{~kg}$ & $16,2 \mathrm{~d}$ & $17,7 \mathrm{~d}$ & $22,2 \mathrm{c}$ & $18,7 \mathrm{~b}$ \\
& $1 \mathrm{~kg}$ & $29,6 \mathrm{a}$ & $23,5 \mathrm{c}$ & $31,0 \mathrm{a}$ & $28,1 \mathrm{a}$ \\
\cline { 2 - 5 } & Rerata & $25,3 \mathrm{ab}$ & $23,2 \mathrm{~b}$ & $26,1 \mathrm{a}$ & $(+)$ \\
\hline
\end{tabular}

Keterangan: Angka pada baris dan kolom diikuti dengan huruf sama tidak berbeda pada taraf nyata $(\alpha) 5 \%$ menurut uji DMRT.

$(-)$ :Tidak terjadi interaksi antar faktor

Frekuensi penyiraman tidak nyata berpengaruh terhadap kadar lengas tanah saat pengamatan 25 HST dan 50 HST tetapi data Tabel 3. menunjukkan bahwa kadar lengas tanah pada petak yang disiram setiap tiga hari cenderung lebih tinggi. Saat pengamatan 75 HST, frekuensi penyiraman berpengaruh nyata terhadap kadar lengas tanah dimana kadar lengas tanah pada petak yang disiram setiap lima hari sekali paling tinggi dan berbeda nyata dengan kadar lengas tanah pada petak yang disiram setiap tiga hari sekali tetapi tidak berbeda nyata dengan kadar lengas tanah pada petak yang disiram setiap hari.

\subsection{Tinggi Tanaman}

Hasil sidik ragam (Anova) menunjukkan bahwa tidak terjadi interaksi antara takaran arang sekam padi dan frekuensi penyiraman terhadap tinggi tanaman setiap waktu pengamatan. Takaran arang sekam padi juga tidak berpengaruh nyata terhadap tinggi tanaman tetapi data pada Tabel 4. menunjukkan bahwa pada setiap waktu pengamatan, tanaman yang diberikan arang sekam padi $0,5 \mathrm{~kg}$ per lubang tanam selalu cenderung lebih tinggi.

Frekuensi penyiraman berpengaruh nyata terhadap tinggi tanaman setiap waktu pengamatan dimana tanaman yang disiram setiap hari selalu paling tinggi dan berbeda nyata dengan tinggi tanaman yang disiram setiap lima hari sekali.

Tabel 4. Tinggi Tanaman $(\mathrm{cm})$

\begin{tabular}{cccccc}
\hline Waktu & Arang & \multicolumn{3}{c}{ Frekuensi Penyiraman } & \multirow{2}{*}{ Rerata } \\
\cline { 3 - 5 } Pengamatan & Sekam & 1 Hari & 3 Hari & 5 Hari & \\
\hline \multirow{3}{*}{25 HST } & Kontrol & 37,6 & 23,6 & 17,2 & $26,1 \mathrm{a}$ \\
& $0,5 \mathrm{~kg}$ & 34,4 & 21,9 & 25,6 & $27,3 \mathrm{a}$ \\
& $1 \mathrm{~kg}$ & 23,8 & 21,7 & 19,3 & $21,6 \mathrm{a}$ \\
\cline { 2 - 5 } & Rerata & $32,0 \mathrm{a}$ & $22,4 \mathrm{~b}$ & $20,7 \mathrm{~b}$ & $(-)$ \\
\hline \multirow{5}{*}{$50 \mathrm{HST}$} & Kontrol & 58,6 & 42,8 & 29,0 & $43,5 \mathrm{a}$ \\
& $0,5 \mathrm{~kg}$ & 55,8 & 46,6 & 46,1 & $49,5 \mathrm{a}$ \\
& $1 \mathrm{~kg}$ & 48,6 & 52,6 & 34,9 & $45,3 \mathrm{a}$ \\
\cline { 2 - 5 } & Rerata & $54,3 \mathrm{a}$ & $47,3 \mathrm{a}$ & $36,7 \mathrm{~b}$ & $(-)$ \\
\hline \multirow{3}{*}{$75 \mathrm{HST}$} & Kontrol & 79,2 & 71,4 & 41,1 & $63,9 \mathrm{a}$ \\
& $0,5 \mathrm{~kg}$ & 77,3 & 71,4 & 67,6 & $72,1 \mathrm{a}$ \\
& $1 \mathrm{~kg}$ & 74,7 & 82,1 & 47,7 & $68,1 \mathrm{a}$ \\
\hline & Rerata & $77,1 \mathrm{a}$ & $75,0 \mathrm{a}$ & $52,1 \mathrm{~b}$ & $(-)$ \\
\hline
\end{tabular}

Keterangan: Angka pada baris dan kolom diikuti dengan huruf sama tidak berbeda pada taraf nyata $(\alpha) 5 \%$ menurut uji DMRT.

$(-)$ :Tidak terjadi interaksi antar faktor

\subsection{Diameter Batang}

Hasil sidik ragam (Anova) menunjukkan bahwa terjadi interaksi antara takaran arang sekam padi dan frekuensi penyiraman terhadapdiameter batang 50 HST dan 75 HSTdimana batang tanaman yang diberikan arang sekam padi dengan takaran 0,5 g per lubang tanam kemudian disiram setiap hari sekali selalu paling besar.

Takaran arang sekam padi tidak berpengaruh nyata terhadap diameter batang 25 HST tetapi berpengaruh nyata terhadap diameter batang 50 HST dan 75 HST dimana batang tanaman yang diberikan arang sekam padi dengan takaran $0,5 \mathrm{~kg}$ per lubang tanam selalu paling besar dan nyata berbeda dengan diameter batang tanaman yang tidak diberikan arang sekam maupu yang diberikan arang sekam padi dengan takaran $1 \mathrm{~kg}$ per lubang tanam.

Frekuensi penyiraman tidak berpengaruh terhadap diameter batang saat pengamatan 25 HST tetapi data Tabel 5. Menunjukkan bahwa batang tanaman yang disiram setiap hari cenderung lebih besar sedangkan batang tanaman yang disiram setiap lima hari sekali paling kecil. Saat pengamatan 50 HST dan 75 HST, frekuensi penyiraman berpengaruh nyata terhadap diameter batang dimana batang tanaman yang disiram setiap hari selalu paling besar dan berbeda nyata dengan diameter batang tanaman yang disiram setiap lima hari sekali.

Tabel 5. Diameter Batang (mm)

\begin{tabular}{ccllll}
\hline Waktu & Arang & \multicolumn{3}{c}{ Frekuensi Penyiraman } & \multirow{2}{*}{ Rerata } \\
\cline { 2 - 4 } Pengamatan & Sekam & 1 Hari & 3 Hari & 5 Hari & \\
\hline \multirow{3}{*}{$25 \mathrm{HST}$} & Kontrol & 3,2 & 2,9 & 2,5 & $2,8 \mathrm{a}$ \\
& $0,5 \mathrm{~kg}$ & 3,2 & 2,7 & 2,7 & $2,8 \mathrm{a}$ \\
& $1 \mathrm{~kg}$ & 2,9 & 2,5 & 2,6 & $2,7 \mathrm{a}$ \\
\cline { 2 - 5 } & Rerata & $3,1 \mathrm{a}$ & $2,7 \mathrm{a}$ & $2,6 \mathrm{a}$ & $(-)$ \\
\hline \multirow{3}{*}{$50 \mathrm{HST}$} & Kontrol & $4,9 \mathrm{~cd}$ & $3,7 \mathrm{~d}$ & $3,5 \mathrm{~d}$ & $4,0 \mathrm{c}$ \\
& $0,5 \mathrm{~kg}$ & $8,5 \mathrm{a}$ & $6,6 \mathrm{~b}$ & $3,8 \mathrm{~d}$ & $6,3 \mathrm{a}$ \\
& $1 \mathrm{~kg}$ & $6,4 \mathrm{~b}$ & $5,6 \mathrm{bc}$ & $3,4 \mathrm{~d}$ & $5,1 \mathrm{~b}$ \\
\hline \multirow{3}{*}{$75 \mathrm{HST}$} & Rerata & $6,6 \mathrm{a}$ & $5,3 \mathrm{~b}$ & $3,6 \mathrm{c}$ & $(+)$ \\
& Kontrol & $6,4 \mathrm{~b}$ & $4,6 \mathrm{c}$ & $4,5 \mathrm{c}$ & $5,2 \mathrm{c}$ \\
& $0,5 \mathrm{~kg}$ & $10,4 \mathrm{a}$ & $10,4 \mathrm{a}$ & $5,1 \mathrm{bc}$ & $8,6 \mathrm{a}$ \\
& $1 \mathrm{~kg}$ & $9,9 \mathrm{a}$ & $8,7 \mathrm{a}$ & $4,2 \mathrm{c}$ & $7,6 \mathrm{~b}$ \\
\hline & Rerata & $8,9 \mathrm{a}$ & $7,9 \mathrm{a}$ & $4,6 \mathrm{~b}$ & $(+)$ \\
\hline
\end{tabular}

Keterangan: Angka pada baris dan kolom diikuti dengan huruf sama tidak berbeda pada taraf nyata $(\alpha) 5 \%$ menurut uji DMRT $(-)$ :Tidak terjadi interaksi antar faktor

\subsection{Diameter Buah}

Hasil sidik ragam (Anova) menunjukkan bahwa tidak terjadi interaksi antara takaran arang sekam padi dan frekuensi penyiraman terhadap diameter buah.

Takaran arang sekam padi berpengaruh nyata terhadap diameter buah dimana buah dari tanaman yang diberikan arang sekam padi dengan takaran 0,5 $\mathrm{kg}$ per lubang tanam paling besar dan nyata berbeda dengan diameter buah dari tanaman yang tidak diberikan arang sekam.

Frekuensi penyiraman berpengaruh nyata terhadap diameter buah dimana buah dari tanaman yang disiram setiap tiga hari paling besar dan berbeda nyata dengan diameter buah dari tanaman yang disiram setiap lima hari tetapi tidak berbeda nyata dengan diameter buah dari tanaman yang disiram setiap hari.

\begin{tabular}{ccccc}
\multicolumn{2}{l}{ Tabel 6. Diameter Buah $(\mathrm{cm})$} & \multirow{2}{*}{ Rerata } \\
\cline { 2 - 4 } Takaran Arang & \multicolumn{3}{c}{ Frekuensi Penyiraman } & \\
\cline { 2 - 4 } Sekam & 1 Hari & 3 Hari & 5 Hari & \\
\hline Kontrol & 4,0 & 4,4 & $\mathrm{~b}$ \\
$0,5 \mathrm{~kg}$ & 4,7 & 4,8 & 4,6 & $4,5 \mathrm{a}$ \\
$1 \mathrm{~kg}$ & 4,6 & 4,8 & 3,8 & $4,4 \mathrm{a}$ \\
\hline Rerata & $4,5 \mathrm{a}$ & $4,7 \mathrm{a}$ & $3,8 \mathrm{~b}$ & $(-)$ \\
\hline Keterangan : & Angka pada baris dan kolom diikuti dengan huruf sama tidak berbeda pada \\
& taraf nyata $(\alpha)$ 5\% menurut uji DMRT. & \\
& $(-)$ : Tidak terjadi interaksi antar faktor
\end{tabular}

\subsection{Jumlah Buah Per Tanaman}

Hasil sidik ragam (Anova) menunjukkan bahwa tidak terjadi interaksi antara takaran arang sekam padi dan frekuensi penyiraman terhadap jumlah buah per tanaman. Takaran arang sekam padi berpengaruh nyata terhadap jumlah buah per tanaman dimana buah dari tanaman yang diberikan arang sekam padi dengan takaran $0,5 \mathrm{~kg}$ per lubang tanam paling banyak dan nyata berbeda dengan jumlah buah dari tanaman yang tidak diberikan arang sekam maupun jumlah buah dari tanaman yang diberikan arang sekam padi dengan takaran $1 \mathrm{~kg}$ per lubang tanam.

Tabel 7. Jumlah Buah Per Tanaman

\begin{tabular}{|c|c|c|c|c|}
\hline Takaran Arang & & nsi Peny & & \\
\hline Sekam & 1 Hari & 3 Hari & 5 Hari & Rerat \\
\hline Kontrol & 9,4 & 10,6 & 3,4 & $7,8 \mathrm{~b}$ \\
\hline $0,5 \mathrm{~kg}$ & 14,6 & 13,4 & 5,9 & 11,3 \\
\hline $1 \mathrm{~kg}$ & 10,2 & 12,8 & 4,8 & $9,3 \mathrm{~b}$ \\
\hline Rerata & $11,4 \mathrm{a}$ & $12,3 \mathrm{a}$ & $4,7 \mathrm{~b}$ & $(-)$ \\
\hline
\end{tabular}


Frekuensi penyiraman berpengaruh nyata terhadap jumlah buah per tanaman dimana buah dari tanaman yang disiram setiap tiga hari paling banyak dan berbeda nyata dengan jumlah buah dari tanaman yang disiram setiap lima hari tetapi tidak berbeda nyata dengan jumlah buah dari tanaman yang disiram setiap hari.

\subsection{Berat Buah Per Tanaman}

Hasil sidik ragam (Anova) menunjukkan bahwa tidak terjadi interaksi antara takaran arang sekam padi dan frekuensi penyiraman terhadap berat buah per tanaman.Takaran arang sekam padi berpengaruh nyata terhadap berat buah per tanaman dimana buah dari tanaman yang diberikan arang sekam padi dengan takaran $0,5 \mathrm{~kg}$ per lubang tanam paling berat dan nyata berbeda dengan berat buah dari tanaman yang tidak diberikan arang sekam maupun berat buah dari tanaman yang diberikan arang sekam padi dengan takaran $1 \mathrm{~kg}$ per lubang tanam. Frekuensi penyiraman juga berpengaruh nyata terhadap berat buah per tanaman dimana buah dari tanaman yang disiram setiap tiga hari paling berat dan berbeda nyata dengan berat buah dari tanaman yang disiram setiap lima hari maupun berat buah dari tanaman yang disiram setiap hari. Pemberian arang sekam padi dengan takaran $0,5 \mathrm{~kg}$ memberikan hasil total panen per tanaman tertinggi yaitu $646 \mathrm{~g}$ (1,9 t/ha), hal ini disebabkan karena pertumbuhan vegetatif tanaman juga terbaik berupa tanaman yang paling tinggi dan berbatang paling besar, buah yang dihasilkan juga berukuran paling besar dengan jumlah setiap tanaman yang paling banyak

Frekuensi penyiraman tiga hari sekali dengan taraf pemberian 120 liter/tanaman memberikan hasil total panen per tanaman tertinggi yaitu 705,7 $\mathrm{g}$ $(2,075 \mathrm{t} / \mathrm{ha})$

Tabel 8. Berat Buah Per Tanaman (g)

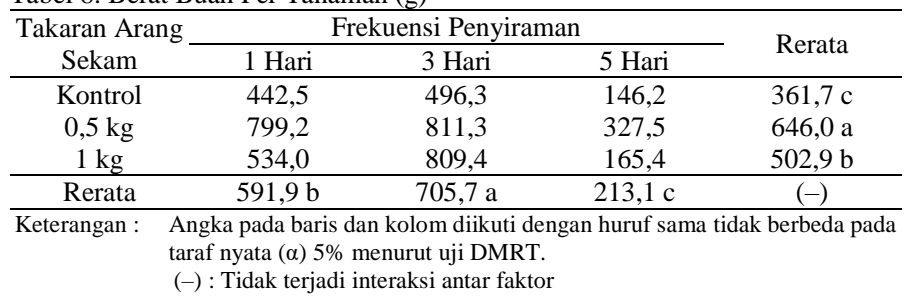

\subsection{Berat Segar Berangkasan}

Hasil sidik ragam (Anova) menunjukkan bahwa tidak terjadi interaksi antara takaran arang sekam padi dan frekuensi penyiraman terhadap berat segar berangkasan.

Takaran arang sekam padi berpengaruh nyata terhadap berat segar berangkasan dimana berangkasan segar dari tanaman yang diberikan arang sekam padi dengan takaran $0,5 \mathrm{~kg}$ per lubang tanam paling berat dan nyata berbeda dengan berat segar berangkasan dari tanaman yang tidak diberikan arang sekam tetapi tidak berbeda nyata dengan berat segar berangkasan dari tanaman yang diberikan arang sekam padi dengan takaran $1 \mathrm{~kg}$ per lubang tanam.Frekuensi penyiraman juga berpengaruh nyata terhadap berat segar berangkasan dimana berangkasan segar dari tanaman yang disiram setiap hari paling berat dan berbeda nyata dengan berat segar berangkasan dari tanaman yang disiram setiap lima hari tetapi tidak berbeda nyata dengan berat segar berangkasan dari tanaman yang disiram setiap tiga hari.

Tabel 9. Berat Segar Berangkasan (g)

\begin{tabular}{|c|c|c|c|c|}
\hline \multirow{2}{*}{$\begin{array}{c}\text { Takaran Arang } \\
\text { Sekam }\end{array}$} & \multicolumn{3}{|c|}{ Frekuensi Penyiraman } & \multirow{2}{*}{ Rerata } \\
\hline & 1 Hari & 3 Hari & 5 Hari & \\
\hline Kontrol & 129,9 & 115,5 & 33,1 & $92,8 \mathrm{~b}$ \\
\hline $0,5 \mathrm{~kg}$ & 210,4 & 213,3 & 80,5 & 168,1 a \\
\hline $1 \mathrm{~kg}$ & 284,8 & 124,2 & 42,8 & $150,6 \mathrm{ab}$ \\
\hline Rerata & $208,4 \mathrm{a}$ & $151,0 \mathrm{a}$ & $52,1 \mathrm{~b}$ & $(-)$ \\
\hline ngan. & lak terja & $i$ antar f & & \\
\hline
\end{tabular}

\subsection{Berat Kering Berangkasan}

Hasil sidik ragam (Anova) menunjukkan bahwa terjadi interaksi antara takaran arang sekam padi dan frekuensi penyiraman terhadap berat kering berangkasan dimana berangkasan kering tanaman yang diberikan arang sekam padi dengan takaran $1 \mathrm{~g}$ per lubang tanam kemudian disiram setiap hari paling berat yang tidak berbeda nyata dengan berat kering berangkasan tanaman yang diberikan arang sekam padi dengan takaran $1 \mathrm{~g}$ per lubang tanam kemudian disiram setiap tiga hari sekali tetapi berbeda nyata dengan berat kering berangkasan tanaman yang diberikan kombinasi perlakuan yang lainnya.

Takaran arang sekam padi berpengaruh nyata terhadap berat kering berangkasan dimana berangkasan kering dari tanaman yang diberikan arang sekam padi dengan takaran $0,5 \mathrm{~kg}$ per lubang tanam paling berat dan nyata berbeda dengan berat kering berangkasan dari tanaman yang tidak diberikan arang sekam tetapi tidak berbeda nyata dengan berat kering berangkasan dari tanaman yang diberikan arang sekam padi dengan takaran $1 \mathrm{~kg}$ per lubang tanam. Frekuensi penyiraman juga berpengaruh nyata terhadap berat kering berangkasan dimana berangkasan kering dari tanaman yang disiram setiap hari paling berat dan berbeda nyata dengan berat kering berangkasan dari tanaman yang disiram setiap lima hari tetapi tidak berbeda nyata dengan berat kering berangkasan dari tanaman yang disiram setiap tiga hari.
Tabel 10. Berat Kering Berangkasan (g)

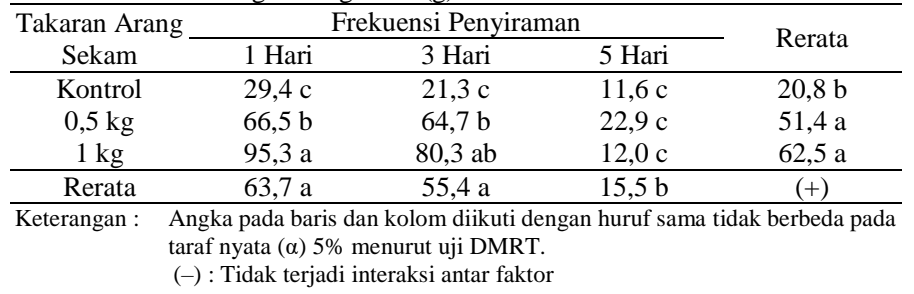

\subsection{Indeks Panen}

Hasil sidik ragam (Anova) menunjukkan bahwa tidak terjadi interaksi antara takaran arang sekam padi dan frekuensi penyiraman terhadap indeks panen. Takaran arang sekam padi juga tidak berpengaruh nyata terhadap indeks panen tetapi data Tabel 13. menunjukkan bahwa indeks panen dari tanaman yang tidak diberikan arang sekam padi cenderung lebih tinggi sedangkan indeks panen dari tanaman yang diberikan arang sekam padi dengan takaran $1 \mathrm{~kg}$ per lubang tanam paling rendah.

Tabel 11. Indeks Panen (\%)

\begin{tabular}{ccccc}
\hline Takaran Arang & \multicolumn{3}{c}{ Frekuensi Penyiraman } & \multirow{2}{*}{ Rerata } \\
\cline { 2 - 4 } Sekam & 1 Hari & 3 Hari & 5 Hari & \\
\hline Kontrol & 79,3 & 81,3 & 81,4 & $80,7 \mathrm{a}$ \\
$0,5 \mathrm{~kg}$ & 78,1 & 79,1 & 81,1 & $79,5 \mathrm{a}$ \\
$1 \mathrm{~kg}$ & 65,3 & 86,7 & 78,3 & $76,8 \mathrm{a}$ \\
\hline Rerata & $74,2 \mathrm{~b}$ & $82,4 \mathrm{a}$ & $80,3 \mathrm{a}$ & $(-)$ \\
\hline Keterangan : & Angka pada baris dan kolom diikuti dengan huruf sama tidak berbeda pada \\
& taraf nyata $(\alpha)$ 5\% menurut uji DMRT. & \\
& $(-)$ : Tidak terjadi interaksi antar faktor &
\end{tabular}

Frekuensi penyiraman berpengaruh nyata terhadap indek panen dimana indeks panen dari tanaman yang disiram setiap tiga hari paling tinggi dan berbeda nyata dengan indeks panen dari tanaman yang disiram setiap hari tetapi tidak berbeda nyata dengan indeks panen dari tanaman yang disiram setiap lima hari. Penyiraman tiga hari sekali memberikan pertumbuhan vegetatif tanaman berupa tinggi dan diameter batang yang tidak terlalu baik tetapi buah yang dihasilkan berukuran paling besar dengan jumlah buah pada setiap tanaman yang paling banyak sehingga berat buah setiap tanaman menjadi paling berat dengan nilai indeks panen yang tertinggi yaitu $82,4 \%$.

\section{Simpulan}

Interaksi antara takaran arang sekam padi dan frekuensi penyiramanterjadi pada suhu tanah 25 HST dan 75 HST, kadar lengas tanah 75 HST, diameter batang 50 HST dan 75 HST serta berat kering berangkasan. Takaran arang sekam padi berpengaruh nyata terhadap suhu tanah 25 HST dan 75 HST, kadar lengas tanah 50 HST dan 75 HST, diameter batang 50 HST dan 75 HST, diameter buah, jumlah buah per tanaman, berat buah per tanaman, berat segar berangkasan dan berat kering berangkasan. Sedangkan frekuensi penyiraman berpengaruh nyata terhadap suhu tanah setiap waktu pengamatan, kadar lengas tanah 75 HST, tinggi tanaman setiap waktu pengamatan, diameter batang 50 HST dan 75 HST, diameter buah, jumlah buah per tanaman, berat buah per tanaman, berat segar berangkasan, berat kering berangkasan dan indeks panen. Takaran arang sekam padi $0,5 \mathrm{~kg}$ memberikan hasil total panen per tanaman tertinggi yakni $646 \mathrm{~g}$ (setara Frekuensi penyiraman tiga hari sekali memberikan hasil total panen per tanaman tertinggi yakni 705,7g)

\section{Pustaka}

BPS TTU. 2010. Timor Tengah Utara Dalam Angka. BPS TTU. Kefamenanu.

Di Mascio, P., Kaiser, S., and Sies, H., 1989. Lycopene as The Most Efficien Biological Carotenoid Singlet Oxygen Quenter. Archives of Biochmistry and Biophysics.

Gomez, K A dan Gomez A A. 1995. Prosedur Statistik untuk Penelitian Pertanian. Edisi ke 2. Jakarta: UI Press.

Hayati E, Sabaruddin dan Rahmawati. 2012. Pengaruh Jumlah Mata Tunas Dan Komposisi Media Tanam Terhadap Pertumbuhan Setek Tanaman Jarak Pagar (Jatropha curcas L.) Jurnal Agrista Vol. 16 No. 3, 2012

Osman, F. 1996. Memupuk Tanaman Padi dan Palawija. Penebar Swadaya, Jakarta.

Rifai, B \& S. R. Soebroto. 1982. Ilmu Memupuk II. CV. Yasa Guna, Jakarta.

Susanto dan Saneto. 1994. Komposisi Zat Gisi Buah Tomat. Jakarta Tatuin P. 2006. Pengaruh Model Ajir dan Pemangkasan Tunas Lateral Terhadap Pertumbuhan dan Hasil Tanaman Tomat. Program Studi Agronomi. Fakultas Pertanian. Unimor. Kefamenanu. 